\title{
PENGARUH MOTIVASI, TINGKAT KESEJAHTERAAN DAN KEDISIPLINAN KERJA TERHADAP ETOS KERJA KARYAWAN PADA PT. BAKTI PERSADA PERKASA MAKASSAR
}

\author{
Lisna1), Syahruddin"1), Muhammad Fachmi ${ }^{1)}$ \\ STIE Amkop Makassar
}

\begin{abstract}
ABSTRAK
Tujuan dilakukannya penelitian ini adalah untuk menganalisis dan menguji pengaruh motivasi, tingkat kesejahteraan dan kedisiplinan, terhadap etos kerja karyawan pada PT. Bakti Persada Perkasa Makassar baik secara parsial maupun secara simultan. Penelitian ini merupakan penelitian explanatory research dengan menggunakan pendekatan kuantitatif. Ukuran besarnya sampel dalam penelitian ini adalah 72 responden yang juga merupakan jumlah besarnya populasi, jadi penentuan sampel menggunakan metode sensus. Adapun teknik pengumpulan data yang digunakan adalah melalui penyebaran kuesioner dan dokumentasi dari data primer dan data sekunder. Metode analisis yang digunakan adalah analisis regresi linier berganda, sedangkan untuk uji hipotesis digunakan Uji-F dan Uji-T. Hasil pengujian hipotesis menunjukkan bahwa secara parsial variabel motivasi berpengaruh positif namun tidak signifikan terhadap etos kerja karyawan, sedangkan variabel tingkat kesejahteraan dan kedisiplinan berpengaruh positif dan signifikan terhadap etos kerja karyawan pada PT. Bakti Persada Perkasa Makassar. Secara simultan variabel motivasi, tingkat kesejahteraan, dan kedisiplinan berpengaruh positif dan signifikan terhadap etos kerja karyawan pada PT. Bakti Persada Perkasa Makassar. Adapun besarnya pengaruh motivasi, tingkat kesejahteraan, dan kedisiplinan terhadap etos kerja karyawan diperoleh hasil sebesar $42,3 \%$. Sedangkan $57,7 \%$ dipengaruhi oleh variabel lain yang tidak diteliti dalam penelitian ini.
\end{abstract}

Kata Kunci : Motivasi, tingkat kesejahteraan, kedisiplinan, etos kerja.

\section{PENDAHULUAN}

Untuk memenuhi sumber daya manusia yang berkulitas, dibutuhkan etos kerja dari setiap sumber daya manusia yang terlibat dalam suatu organisasi termasuk dalam suatu perusahaan. Karena dengan etos kerja yang baik, maka akan terbentuk budaya kerja perusahaan yang baik pula. Menurut Sinamo (2011:39) etos kerja adalah seperangkat perilaku kerja positif yang berakar pada keyakinan yang fundamental, kerjasama yang kental, disertai komitmen yang total.

Menurut Salamun dkk. (2015:83) seorang karyawan yang memiliki etos kerja yang tinggi diindikasikan dengan: (1) kerja keras, dimana karyawan mempunyai sifat mabuk kerja 
untuk dapat mencapai sasaran yang ingin dicapai, (2) disiplin kerja, dimana karyawan memiliki sikap menghormati, menghargai patuh dan taat terhadap peraturan-peraturan yang berlaku, (3) jujur, dimana karyawan dalam menjalankan pekerjaannya sesuai dengan aturan yang sudah ditentukan, (4) tanggung jawab, dimana pekerjaan yang dilakukan merupakan sesuatu yang harus dikerjakan dengan ketekunan dan kesungguhan, (5) rajin, terciptanya kebiasaan pribadi karyawan untuk menjaga dan meningkatkan apa yang sudah dicapai, dan (6) tekun berarti rajin, keras hati, dan bersungguh-sungguh (bekerja, belajar, berusaha, dsb).

Ada 3 (tiga) faktor utama yang dapat digunakan untuk meningkatkan etos kerja karyawan pada PT. Bakti Persada Perkasa Makassar. Ketiga faktor tersebut meliputi motivasi, tingkat kesejahteraan, dan kedisiplin kerja. Etos kerja karyawan pada PT. Bakti Persada Perkasa Makassar dapat dilihat dari kerja keras mereka seperti bekerja lembur, namun beberapa karyawan tidak memanfaatkan jam kerja yang ada dan cenderung mengurangi jam kerja mereka. Dari observasi yang dilakukan banyak diantara karyawan tersebut yang mengisi waktu kerjanya dengan duduk-duduk ngobrol, ataupun keluar kantor untuk urusan-urusan yang tidak berkaitan dengan tugas pekerjaannya. Karyawan juga memiliki ketekunan yang rendah. Dilihat dari pekerjaan tidak selesai karena dipengaruhi rendahnya disiplin dalam bekerja, rendahnya kepatuhan, rendahnya rasa tanggung jawab, dan tidak menunjukkan kemampuan profesional dalam bekerja.

Tanggung jawab karyawan untuk PT. Bakti Persada Perkasa Makassar masih rendah. Dilihat dari masih adanya sebagian karyawan terlihat tidak mengerjakan tanggung jawab tugasnya dengan sungguh-sungguh, ketika pimpinan meminta hasil tanggung jawab tugasnya,karawan cenderung mengumpulkan dengan asal-asalan, tidak diperiksa sebelum diserahkan kepada pimpinan. Hal ini menunjukkan lemahnya kesungguhan dan ketekunan mereka dalam bekerja. Kejujuran karyawan masih kurang. Hasil observasi menunjukkan beberapa karyawanyang mencuri waktu pada jam kerja seperti, duduk depan layar komputer, namun mata justru menyasar ke laman-laman media sosial. Hal ini terjadi ketika sedang tidak mood untuk melakukan tugasnya atau bosan dengan tekanan tinggi dari atasan, dan bergosip dengan rekan kerja sampai melupakan kewajiban untuk bekerja. Rendahnya etos kerja karyawan pada PT. Bakti Persada Perkasa Makassar disebabkan adanya prinsip bahwa bekerja hanya untuk mendapatkan uang, tidak adanya kontribusi dari diri karyawan untuk kemajuan organisasi, dan perasaan jika pekerjaan yang selama ini dijalankan tidak dapat mewujudkan cita-cita yang diinginkan.

Berdasarkan fenomena tersebut, penulis tertarik untuk melakukan penelitian untuk mengetahui pengaruh motivasi, tingkat kesejahteraan, dan kedisiplinan kerja terhadap etos kerja karyawan pada PT. Bakti Persada Perkasa Makassar. 


\section{METODE PENELITIAN}

Peneliti yang menggunakan pendekatan kuantitatif akan menguji suatu teori dengan cara merinci suatu hipotesis-hipotesis. Penulis melakukan penelitian pada PT.Bakti Persada Perkasa Makassar Alasannya pada bagian inilah yang berhubungan langsung dengan pelayanan publik (pelanggan) yang membutuhkan kesabaran dan kesadaran diri dalam bekerja. Adapun jumlah populasi (karyawan) yang pada PT. Bakti Persada Perkasa Makassar adalah 72 orang. Sedangkan teknik sampling yang digunakan yaitu dengan sampel jenuh, dimana ditetapkan sampel 72 orang karyawan berdasarkan jumlah populasinya.

Dalam penelitian ini, instrument penelitian yang digunakan adalah kuisioner (angket), dengan skala likert. Dalam penelitian ini kuisioner digunakan untuk mengumpulakan data dari para responden yang telah ditentukan. Kriteria penilaian dari pernyataan tersebut memiliki 5 alternatif jawaban, yaitu untuk pernyataan positif mempunyai nilai Sangat Setuju=5. Setuju=4, Cukup Setuju=3, Tidak Setuju=2, dan Sangat Tidak Setuju=1.

Dalam penelitian ini, statistika deskriptif dilakukan untuk menjawab identifikasi masalah penelitian yang telah ditetapkan. Analisis statistik yang digunakan dalam penelitian ini adalah Analisis Regresi Berganda. Adapun rumus regresi linear berganda adalah sebagai berikut:

$$
\begin{aligned}
& \mathrm{Y}=\mathrm{a}+\mathrm{b} 1 \times 1+\mathrm{b} 2 \times 2+\mathrm{b} 3 \times 3+\mathrm{e} \\
& \text { Keterangan: } \\
& \mathrm{Y}=\text { Etos Kerja } \\
& \mathrm{X}_{1}=\text { Motivasi } \\
& \mathrm{X}_{2}=\text { Tingkat Kesejahteraan } \\
& \mathrm{X}_{3}=\text { Kedisiplinan } \\
& \mathrm{b}=\text { Koefisien regresi }
\end{aligned}
$$

\section{HASIL PENELITIAN}

\section{Uji Instrumen Penelitian}

Uji validitas digunakan untuk mengukur sah atau valid tidaknya suatu kuesioner. Pada penelitian ini menggunakan sampel untuk uji kuesioner sebanyak 72 orang responden dengan signifikansi $5 \%$, dari sini di dapat nilai $d f=n-2, d f=72-2=70$. Pada tabel $r$ product moment untuk signifikansi 5\%, didapatkan angka $r$ tabel=0,2319. Selanjutnya dibandingkan nilai $r$ yang di dapat dari tabel $r$ dengan $r$ hasil perhitungan. Jika $r$ ditabel $r<r$ hasil hitungan, makan pernyataan itu valid. 
Tabel 1. Hasil Uji Validitas Kuesioner

\begin{tabular}{|c|c|c|c|c|}
\hline Variabel & Indikator & R hitung & R tabel & Keterangan \\
\hline \multirow{17}{*}{$\begin{array}{c}\text { Motivasi } \\
(\mathrm{x} 1)\end{array}$} & $\mathrm{x} 1.1$ & 0,604 & 0,2319 & Valid \\
\hline & $x 1.2$ & 0,538 & 0,2319 & Valid \\
\hline & $x 1.3$ & 0,562 & 0,2319 & Valid \\
\hline & $\times 1.4$ & 0,671 & 0,2319 & Valid \\
\hline & $x 1.5$ & 0,605 & 0,2319 & Valid \\
\hline & $x 1.6$ & 0,538 & 0,2319 & Valid \\
\hline & $x 1.7$ & 0,573 & 0,2319 & Valid \\
\hline & $x 1.8$ & 0,521 & 0,2319 & Valid \\
\hline & $\mathrm{x} 1.9$ & 0,556 & 0,2319 & Valid \\
\hline & $x 1.10$ & 0,572 & 0,2319 & Valid \\
\hline & $\mathrm{x} 1.11$ & 0,629 & 0,2319 & Valid \\
\hline & $x 1.12$ & 0,498 & 0,2319 & Valid \\
\hline & $\mathrm{x} 1.13$ & 0,586 & 0,2319 & Valid \\
\hline & $x 1.14$ & 0,586 & 0,2319 & Valid \\
\hline & $\mathrm{x} 1.15$ & 0,581 & 0,2319 & Valid \\
\hline & $\mathrm{x} 1.16$ & 0,599 & 0,2319 & Valid \\
\hline & $\mathrm{x} 1.17$ & 0,590 & 0,2319 & Valid \\
\hline \multirow{10}{*}{$\begin{array}{c}\text { Tingkat } \\
\text { Kesejahteraan } \\
(x 2)\end{array}$} & $x 2.1$ & 0,544 & 0,2319 & Valid \\
\hline & $x 2.2$ & 0,482 & 0,2319 & Valid \\
\hline & $\times 2.3$ & 0,567 & 0,2319 & Valid \\
\hline & $x .2 .4$ & 0,622 & 0,2319 & Valid \\
\hline & $x 2.5$ & 0,693 & 0,2319 & Valid \\
\hline & $x 2.6$ & 0,682 & 0,2319 & Valid \\
\hline & $\times 2.7$ & 0,703 & 0,2319 & Valid \\
\hline & $x 2.8$ & 0,597 & 0,2319 & Valid \\
\hline & $\times 2.9$ & 0,495 & 0,2319 & Valid \\
\hline & $x 2.10$ & 0,497 & 0,2319 & Valid \\
\hline \multirow{5}{*}{$\begin{array}{l}\text { Kedisiplinan } \\
\text { (x3) }\end{array}$} & x3.1 & 0,714 & 0,2319 & Valid \\
\hline & $x 3.2$ & 0,625 & 0,2319 & Valid \\
\hline & $x 3.3$ & 0,432 & 0,2319 & Valid \\
\hline & $\times 3.4$ & 0,594 & 0,2319 & Valid \\
\hline & $\times 3.5$ & 0,726 & 0,2319 & Valid \\
\hline \multirow{5}{*}{$\begin{array}{l}\text { Etos Kerja } \\
(Y)\end{array}$} & $\mathrm{y} 1.1$ & 0,524 & 0,2319 & Valid \\
\hline & $y 1.2$ & 0,505 & 0,2319 & Valid \\
\hline & $y 1.3$ & 0,667 & 0,2319 & Valid \\
\hline & $\mathrm{y} 1.4$ & 0,708 & 0,2319 & Valid \\
\hline & $\mathrm{y} 1.5$ & 0,611 & 0,2319 & Valid \\
\hline
\end{tabular}

Sumber : Data kuesioner diolah, 2018

Berdasarkan tabel 1 uji validitas, diketahui bahwa seluruh item pertanyaan dalam penelitian ini adalah valid, yang ditunjukkan dengan nilai dari masing-masing item 
pertanyaan memiliki nilai Pearson Correlation positif dan lebih besar daripada nilai $r$ tabel 0,2319 (uji dua arah).

Suatu kuesioner dikatakan reliable atau handal jika memberikan nilai cronbach alpha di atas 0,60. Hasil uji reliabel disajikan pada tabel 2 berikut ini.

Tabel 2. Hasil Uji Reliabilitas Kuesioner

\begin{tabular}{|c|c|}
\hline Cronbach's Alpha & Jumlah Indikator \\
\hline 0,894 & 41 \\
\hline
\end{tabular}

Sumber : Data kuesioner diolah, 2018

Berdasarkan tabel diatas, nilai Cronbach's Alpha 0,894 menyatakan bahwa nilai koefisien sangat baik, yang berarti bahwa semua indikator yang diuji mempunyai tingkat reliabilitas yang sangat baik.

\section{Hasil Analisis Regresi Linier Berganda}

Perhitungan statistik dalam analisis regresi linier berganda yang digunakan dalam penelitian ini adalah dengan menggunakan bantuan program komputer SPSS for Windows versi 23,0 sebagai berikut:

Tabel 3. Hasil Uji Regresi Linier Berganda

\begin{tabular}{|l|r|r|r|l|}
\hline \multicolumn{1}{|c|}{ Variabel } & $\begin{array}{c}\text { Koef.Regersi } \\
(\boldsymbol{\beta})\end{array}$ & T hitung & $\begin{array}{c}\text { Nilai } \\
\mathbf{P}\end{array}$ & Keterangan \\
\hline Motivasi Kerja $(\mathrm{x} 1)$ & 0,006 & 0,107 & .915 & Signifikan \\
\hline Tingkat Kesejahteraan (x2) & 0,243 & 2,823 & .006 & Signifikan \\
\hline Kedisiplinan (x3) & 0,376 & 3,032 & .003 & Signifikan \\
\hline Konstanta $=1,509$ & \\
\hline $\mathrm{F}$ hitung $=18,326 \quad \mathrm{P}=0,000$ \\
\hline $\mathrm{F}$ tabel $=2,74 \quad \mathrm{t}$ tabel $=1,995$ \\
$\mathrm{R}=0,940 \mathrm{R}=0,884$
\end{tabular}

Model persamaan regresi yang dapat dituliskan dari hasil tersebut dalam bentuk persamaan regresi unstandardized adalah sebagai berikut :

$$
Y=1,509+0,006 \times 1+0,243 \times 2+0,376 \times 3
$$

Dari persamaan yang terbentuk di atas dapat dijelaskan interpretasinya sebagai berikut : 
1. Nilai koefisien konstanta adalah sebesar 1,509. Hal ini berarti bahwa, apabila kenaikan variabel atau nilai dari motivasi (x1) tingkat kesejahteraan (x2), dan kedisiplinan $(x 3)$ di obyek penelitian adalah sama dengan nol, maka besarnya variabel dependen etos kerja $(Y)$ di lokasi tersebut akan sebesar 1,509 persen. Hal ini menandakan apabila variabel independen yang meliputi motivasi, tingkat kesejahteraan, dan kedisiplinan bernilai nol, maka skor etos kerja karyawan adalah sebesar 1,509 .

2. Nilai koefisien regresi yang dimiliki motivasi $(x 1)$ sebesar 0,006 dan memiliki hubungan yang positif terhadap etos kerja (Y). Maka apabila nilai motivasi $(\mathrm{X} 1)$ mengalami kenaikan sebesar satu poin, sementara nilai variabel independen lainnya (tingkat kesejahteraan dan kedisiplinan) bersifat tetap, maka tingkat variabel etos kerja $(Y)$ akan meningkat sebesar 0,006 persen. Hal ini berarti apabila terjadi peningkatan variabel motivasi sebesar satu satuan maka akan terjadi peningkatan skor etos kerja karyawan sebesar 0,006.

3. Nilai koefisien regresi yang dimiliki tingkat kesejahteraan (x2) sebesar 0,243 dan memiliki hubungan yang positif terhadap etos kerja (Y). Maka apabila nilai tingkat kesejahteraan (x2) mengalami kenaikan sebesar satu poin, sementara nilai variabel independen lainnya (motivasi dan kedisiplinan) bersifat tetap, maka tingkat variabel etos kerja $(Y)$ akan meningkat sebesar 0,243 persen. Hal ini berarti apabila terjadi peningkatan variabel tingkat kesejahteraan sebesar satu satuan maka akan terjadi peningkatan skor etos kerja karyawan sebesar 0,243.

4. Nilai koefisien regresi yang dimiliki kedisiplinan $(x 3)$ sebesar 0,376 dan memiliki hubungan yang positif terhadap etos kerja ( $Y$ ). Maka apabila nilai kedisiplinan (x3) mengalami kenaikan sebesar satu poin, sementara nilai variabel independen lainnya (motivasi dan tingkat kesejahteraan) bersifat tetap, maka tingkat variabel etos kerja (Y) akan meningkat sebesar 0,376 persen. Hal ini berarti apabila terjadi peningkatan variabel kedisiplinan sebesar satu satuan maka akan terjadi peningkatan skor etos kerja karyawan sebesar 0,376. 
Tabel 4. Hasil Uji Parsial

\begin{tabular}{|c|c|c|c|c|c|c|}
\hline \multicolumn{7}{|c|}{ Coefficients $^{a}$} \\
\hline \multirow{2}{*}{\multicolumn{2}{|c|}{ Model }} & \multicolumn{2}{|c|}{ Unstandardized Coefficients } & \multirow{2}{*}{$\begin{array}{c}\text { Standardized } \\
\text { Coefficients } \\
\text { Beta }\end{array}$} & \multirow[b]{2}{*}{$\mathrm{t}$} & \multirow[b]{2}{*}{ Sig. } \\
\hline & & $\mathrm{B}$ & Std. Error & & & \\
\hline \multirow[t]{4}{*}{1} & (Constant) & 1.509 & 2.650 & & .569 & .571 \\
\hline & Motivasi & .006 & .055 & .016 & .107 & .915 \\
\hline & Tingkat Kesejahteraan & .243 & .086 & .387 & 2.823 & .006 \\
\hline & Kedisiplinan & .376 & .124 & .357 & 3.032 & .003 \\
\hline
\end{tabular}

a. Dependent Variable: Etos Kerja

Hasil analisis uji t diatas adalah sebagai berikut :

1. Nilai thitung pada variabel motivasi $(x 1)$ adalah 0,107 dengan tingkat signifikansi 0,915 . Karena nilai $\mathrm{t}$ hitung 0,107 < nilai $\mathrm{t}$ tabel 1,995 dan tingkat signifikansi 0,915> probabilitas signifikansi $\alpha=0,05$ maka secara individual (parsial) variabel motivasi tidak berpengaruh dan tidak signifikan terhadap etos kerja karyawan pada PT. Bakti Persada Perkasa Makassar. Hipotesis 1 ditolak.

2. Nilai t hitung pada variabel tingkat kesejahteraan (x2) adalah 2,823 dengan tingkat signifikansi 0,006. Karena nilai t hitung 2,823 > nilai t tabel 1,995 dan tingkat signifikansi $0,006<$ probabilitas signifikansi $\alpha=0,05$, maka secara individual (parsial) variabel tingkat kesejahteraan berpengaruh positif dan signifikan terhadap etos kerja karyawan pada PT. Bakti Persada Perkasa Makassar. Hipotesis 2 diterima.

3. Nilai t hitung pada variabel tingkat kedisiplinan (x3) adalah 3,032 dengan tingkat signifikansi 0,003. Karena nilai thitung 3,032 > nilai t tabel 1,995 dan tingkat signifikansi $0,003<$ probabilitas signifikansi $\alpha=0,05$, maka secara individual (parsial) variabel kedisiplinan berpengaruh positif dan signifikan terhadap etos kerja karyawan pada PT. Bakti Persada Perkasa Makassar. Hipotesis 3 diterima.

Tabel 5. Hasil Uji Simultan

ANOVA $^{\mathrm{a}}$

\begin{tabular}{|ll|r|r|r|r|r|}
\hline Model & & Sum of Squares & df & Mean Square & F & Sig. \\
\hline 1 & Regression & 219.255 & 3 & 73.085 & 18.326 & $.000^{\mathrm{b}}$ \\
& Residual & 271.190 & 68 & 3.988 & & \\
& Total & 490.444 & 71 & & & \\
& & & & & \\
\end{tabular}
a. Dependent Variable: Etos Kerja
b. Predictors: (Constant), Kedisiplinan, Tingkat Kesejahteraan, Motivasi

Dari uji ANOVA atau Uji $F$ diatas didapat nilai $F$ Hitung sebesar 18,326 dengan probabilitas 0,000 . Adapun $F$ tabel adalah 2,74. Karena $F$ hitung $>F$ tabel $(18,326>2,74)$ 
dan probabilitas jauh lebih kecil dari 0,05 maka model regresi dapat digunakan untuk memprediksi etos kerja (variabel dependen) atau dapat dikatakan bahwa seluruh variabel independen yaitu motivasi, tingkat kesejahteraan, dan kedisiplinan secara simultan berpengaruh positif dan signifikan terhadap etos kerja pada PT. Bakti Persada Perkasa Makassar. Hipotesis 4 diterima.

\section{SIMPULAN}

Berdasarkan hasil penelitian dan pembahasan, maka dapat ditarik kesimpulan sebagai berikut :

1. Motivasi tidak berpengaruh positif dan tidak signifikan terhadap etos kerja karyawan pada PT. Bakti Persada Perkasa Makassar. Hal ini dibuktikan dengan nilai t hitung yang lebih kecil dari nilai t tabel $(0,107)<(1,995)$ dan nilai $P$ yang lebih besar dari $\alpha$ $(0,95>0,05)$.

2. Terdapat pengaruh positif dan signifikan variabel tingkat kesejahteran terhadap etos kerja karyawan pada PT. Bakti Persada Perkasa Makassar. Hal ini dibuktikan dengan nilai t hitung yang lebih besar dari nilai t tabel $(2,823)>(1,995)$ dan nilai $P$ yang lebih kecil dari $\alpha(0,006<0,05)$.

3. Terdapat pengaruh positif dan signifikan variabel kedisiplinan terhadap etos kerja karyawan pada PT. Bakti Persada Perkasa Makassar. Hal ini dibuktikan dengan nilai t hitung yang lebih besar dari nilai t tabel $(3,032)>(1,995)$ dan nilai $P$ yang lebih kecil dari $\alpha(0,003<0,05)$.

4. Terdapat pengaruh positif dan signifikan variabel motivasi, tingkat kesejahteraan, dan kedisiplinan terhadap etos kerja karyawan pada PT. Bakti Persada Perkasa Makassar. Hal ini dibuktikan dengan nilai $F$ hitung yang lebih besar dari nilai $F$ tabel $(18,326)>(2,74)$ dan nilai $P$ yang lebih kecil dari $\alpha(0,000<0,05)$.

\section{REFERENSI}

Anoraga, Panji dan Sri Suyati, 2015, Perilaku Keorganisasian, Pustaka Jaya, Jakarta.

Arikunto, Suharsimi. 2013. Prosedur Penelitian: Suatu Pendekatan Praktik. Rineka Cipta, Jakarta.

As'ad, Mohammad. 2009. Seri IImu Sumber Daya Manusia: Psikologi Industri,. Edisi IV. Liberty, Yogyakarta. 
Arep, Ishak dan Hendri Tanjung. 2013. Manajemen Sumber Daya Manusia. Universitas Trisakti: Jakarta.

Creswell John.W. 2014. Penelitian Kualitatif \& Desain Riset. Pustaka Pelajar, Yogyakarta.

Handoko, T. Hani. 2012. Manajemen Personalia dan Sumber Daya Manusia, BPFE. Yogyakarta.

Hasibuan, Malayu, S,P, 2012. Manajemen Sumber Daya Manusia . Cetakan Keenambelas. Bumi Aksara, Jakarta

Istijanto. 2005. Riset Sumber Daya Manusia, Cara Praktis Mendeteksi DimensiDimensi Kerja Karyawan. Gramedia Pustaka Utama. Jakarta

Maslow, H.Abraham, 2010, Motivation and Personality. Rajawali, Jakarta

Mondy, R. Wayne, 2010, Human Resource Management. Eleventh EditionPrentice Hall, New Jersey.

Nitisemito, S. Alex, 2010, Manajemen Personalia, Ghalia Indonesia, Jakarta

Rivai, Veithzal, 2008. Manajemen Sumber Daya Manusia untuk Perusahaan, PT. Remaja Rosda Karya ; Bandung

Salamun, Sumardi, Sadilah, Emiliana, Sumintarsih, Sudijono, dan Suhartinah. 2015. Persepsi Tentang Etos Kerja: Kaitannya Dengan Nilai Budaya Masyarakat Daerah Istimewa Yogyakarta. Departemen Pendidikan Dan Kebudayaan RI, Yogyakarta.

Samsudin, Sadili. 2010. Manajemen Sumber Daya Manusia. Pustaka Setia, Bandung.

Sastrohadiwiryo, B. Siswanto. 2008. Manajemen Tenaga Kerja Indonesia, edisi 2. PT. Bumu Aksara, Jakarta. 
Sedarmayanti, 2011. Manajemen Sumber Daya Manusia, Reformasi Birokrasi dan Manajemen Pegawai Negeri Sipil (cetakan kelima). PT Refika Aditama, Bandung.

Siagian, Sondang. 2014. Organisasi Kepemimpinan dan Perilaku Administrasi. PT. Gunung Agung, Jakarta.

Simamora, Henry, 2008. Manajemen Sumber Daya Manusia. STIE YKPN. Yogyakarta.

Sinamo, Jansen H. 2011. Etos Kerja Profesional Navigator Anda Menuju Sukses. PT Spirit Mahardika. Jakarta

Singodimedjo, Markum. 2015. Manajemen Sumber Daya Manusia. SMMAS, Surabaya.

Stoner, J.A.F dan R.E. Freeman. 2014. Manajemen. Jilid 1. Edisi Kelima. Intermedia. Jakarta

Sugiyono. 2011. Metode Penelitian Kuantitatif, Kualitatif dan R\&D. Afabeta. Bandung.

Sutrisno, Edi. 2009. Manajemen Sumber Daya Manusia, Edisi pertama. Kencana Prenada Media Group, Jakarta.

Wirawan, 2015. Evaluasi Kinerja Sumber Daya Manusia (Teori, Aplikasi, dan Penelitian). Salemba Empat, Jakarta.

Yuniarsih, Tjutju dan Suwatno. 2009. Manajemen Sumber Daya Manusia. Alfabeta, Bandung. 